https://doi.org/10.18485/iipe_response2covid19.2021.ch10

\title{
THE COVID-19 PANDEMIC AND THE EURASIAN ECONOMIC UNION: STRENGTH TESTS AND LESSONS FOR THE INTEGRATION PROJECT
}

\begin{abstract}
Dmitriy V. Galushko ${ }^{1}$
Abstract: The coronavirus pandemic is not only in the scale of human and economic losses but in the ability of both national and integration institutions to withstand the pandemic and the economic crisis. Against the backdrop of the current crisis caused by the COVID-19 pandemic, countries are becoming increasingly aware of the need to join forces within the framework of integration organizations to solve global problems and find answers to great challenges. The latter creates significant risks for society, the economy, and the public administration system, but at the same time opens up new opportunities and prospects. The Eurasian Economic Union is no exception.

The author conducted a study of the measures taken by the member states within the EAEU to prevent the spread of coronavirus infection and overcome the negative consequences caused by it.

The work includes the study of the joint activities of the EAEU and the member states, within which, after a pause, the "emergency" regime was switched on and rhythmic work was initiated. The results of the research indicated the need for increased coordination between the Eurasian Economic Union and its member states in response to COVID-19 and the development of a more "visible" and comprehensive program of action and its implementation, which would contribute to the formation of a more holistic response of the entire organisation to new challenges. New crisis phenomena may await us, in connection with which the EAEU needs to have an adequate anti-crisis strategy for future activities ready.

Keywords: Eurasian Economic Union, Eurasian integration, COVID-19, pandemic, interaction, regional integration, emergency regime.
\end{abstract}

\footnotetext{
${ }^{1}$ Associate Professor of the Department of Legal Regulation of Economic Activities, Financial University under the Government of the Russian Federation, Financial University, Moscow, Russia, galushkodv@gmail.com.
} 


\section{INTRODUCTION}

At all times, human health has been considered one of the most important values of life, as the most personal good. The ancient Romans used to say, "Valetudo bonum est" (health is the greatest wealth). In the modern world, full of numerous natural and anthropogenic threats and cataclysms, especially in the light of the ongoing COVID-19 pandemic, human health is becoming even more important and relevant.

In general, health is interpreted as a natural state of the body, characterized by its balance with the environment and the absence of any painful changes. Human health is determined by a complex of biological (hereditary and acquired) and social factors. The latter are so important in maintaining a state of health or in the appearance and development of a disease that it is written in the preamble of the Constitution of the World Health Organization: "Health is a state of complete physical, mental and social well-being and not merely the absence of disease or infirmity" (WHO, 1946). This definition of the concept of "health" is the clearest, understandable, and complete one and includes, first of all, the biological, social, and psychological aspects of this problem.

On March 11, 2020, the new coronavirus COVID-19 was declared a pandemic (WHO Director-General, 2020). This means that this new virus and the disease that it causes have spread on a global scale. A. Guterres, Secretary-General of the United Nations (UN), noted that the current pandemic was the biggest crisis in global health over the past 75 years (Guterres, 2020). The previous disease that had the status of a pandemic was swine flu, which lasted from 2009 to 2010. Why is this new coronavirus causing so much fear?

First, it is the speed of its spread and the long absence of medicines with proven clinical efficacy. It has been confirmed that COVID-19 is dangerous for the elderly and people with chronic diseases. These categories are already vulnerable, and with the spread of COVID-19, their vulnerability has increased significantly.

Secondly, it is the vulnerability of national health systems. Many countries have exceeded their capabilities (material resources, medical personnel) to provide medical care to people who need it. Philosophers and representatives of bioethics have already started a discussion about determining the priority in the provision of medical care (see e.g., Bagenstos, 2020; Holm, 2020). At the same time, A. Guterres notes that the costs of health protection should be increased to meet urgent needs with full respect for human rights (Guterres, 2020).

Thirdly, that is because of the unprecedented measures that countries implement in order to protect the health of their citizens: borders are closed, air traffic is canceled, emergency regimes are declared. A number of freedoms secured by human rights are subject to restrictions, in particular, on free movement. 
Fourth, COVID-19 will have a significant impact on the global economy - the sphere of production, international trade, logistics, and business. A significant number of people should support their business or, if they are left without a job, count on their savings and social assistance from the states.

\section{THE PANDEMIC IN THE INTEGRATION CONTEXT}

The modern world is globalized and integrated. Freedom of movement is an opportunity to get to another place on the continent within a day through air communication. COVID-19 was detected in Wuhan, the Hubei Province in the People's Republic of China, at the end of December 2019. The quarantine was introduced about a month later (January 2020), and about three months after the COVID-19 infection was detected, it was confirmed on all continents. Of course, globalization and international integration have become one of the factors contributing to the spread of COVID-19 around the world. The global nature of the epidemic was only a confirmation of the pervasive nature of globalization and regional integration, without which there would have been no instant spread of the disease, as well as the reaction that followed it (Gromyko, 2020, p. 7).

Attention should be paid to the International Health Regulations (hereinafter referred to as the IHR) (WHO, 2005), which, by their legal nature, are an international treaty, a binding document for all UN member states. The IHR are focused on preventing the most serious risks in the field of health of cross-border nature (Ferhani, Rushton, 2020, p. 460).

The IHR determines what constitutes a major health-care emergency on a global scale. Namely, an extraordinary event: 1) carries a risk to the health of the population in other states as a result of the international spread of the disease; and 2) may require coordinated international measures in response. COVID-19 corresponds to these characteristics, and that is why it belongs to the category of emergency situations in the field of healthcare of international importance. Analysing the IHR, it should be noted that measures at the level of public health should be proportionate to the risks to public health and limited by them, should not create excessive obstacles to international transport and trade (WHO, 2005). It is this proportionality that is criticized by some countries: measures to prevent the spread of COVID-19 are not commensurate with the consequences for the economy and society.

In any case, the deepening of integration processes has led to the significant growth of international organisations, which has contributed to mobility among people. In this context, health care, as such, is no longer limited by state borders. The growing mobility of people, one way or another, leads to the emergence of issues 
both in the field of social security and in the field of medicine. The Eurasian Economic Union (hereinafter referred to as EAEU) is no exception in this regard. The main purpose of the creation of the EAEU was, on the one hand, to comprehensively modernize, increase competitiveness and cooperation between the national economies of the member states. On the other hand, it is the promotion of stable development of countries to improve the standard of living of the population by ensuring the free movement of goods, services, capital and labour.

The Treaty on the EAEU, which entered into force on 1 January 2015, forms common economic (basic) values, regulates business processes in detail, and creates a favourable organizational and legal environment for national investors from the EAEU member states in the Eurasian space (EAEU, 2014). However, there are certain circumstances of objective reality that can cause economic harm to economic interests despite the strict regulatory regulation of the impact of unfavourable anthropogenic factors. Such factors include force majeure circumstances (natural and man-made emergencies, as well as circumstances that form a situation in a certain territory, often referred to as an emergency).

On the EAEU territory, equality is observed in the legal relations of economic investors from the member states when compensating for damage caused by civil unrest, military actions, revolutions, riots, the introduction of a state of emergency or other similar circumstances (paragraph 77 of the Protocol on Trade in Services, establishment, activity and implementation of investments - Annex No. 16 to the Treaty on the EAEU). At the same time, according to the analysis of the annexes to the Treaty on the EAEU, natural and man-made emergencies are among the force majeure circumstances that can cause not only losses to economic entities but also lead to crisis phenomena in national economic systems. The regulation of the specifics of compensation for damage and collective response to such emergencies is not yet provided for by the agreements within the framework of the EAEU.

The EAEU Treaty imposes certain obligations on the EAEU member states in the field of joint actions in the event of an emergency and activities to prevent it. Thus, by Annex No. 12 to the Treaty on the EAEU (Protocol on the application of sanitary, veterinary-sanitary and quarantine phytosanitary measures), the member states are obliged to take coordinated measures aimed at preventing the spread and eliminating the consequences of sanitary infections and emergency situations, as well as acts of terrorism with the use of radiation, chemical and biologically active substances.

However, at present, the Decree of the Government of the Russian Federation of 21 May 2007 No. 304 "On the classification of natural and man-made emergencies" (Government, 2007) (unlike the similar decree of the Government of the Russian Federation of 13.09.1996 No. 1094, which has lost its force) does 
not classify a cross-border type of emergency situation- the damaging factors that go beyond the borders of the Russian Federation, or that occur abroad and affect the territory or economic interests of the Russian Federation. In addition, technical regulations and international agreements on a joint response to emergencies and circumstances have not been developed within the framework of the EAEU at the moment. Thus, the Russian national emergency management system in the field of collective actions to neutralize threats and eliminate the adverse consequences of the emergency situation developing on the territory of the EAEU requires greater legal regulation (Betskov, Tagirov, 2017, p.8). Such a situation significantly affects the entire integration progress, as well as interaction both with the Union itself and with the member states, reducing the effectiveness of the fight against emergencies and of the legal mechanisms for protecting the economic interests of subjects in the EAEU space.

\section{THE EAEU MEASURES TAKEN IN RESPONSE TO THE COVID-19 PANDEMIC}

The corona crisis became a challenge for Eurasian integration, but it did not stop it. The work of the institutions has been adjusted to take into account the need to resolve urgent problems of mutual trade. The efforts of the Eurasian Economic Commission (hereinafter referred to as EEC), together with the national governments, were aimed at ensuring economic stability and combating the spread of infection. Against the background of the pandemic, the priority of cooperation between the EAEU member states has clearly identified itself - the regulation of the movement of factors and the results of economic activity (Kondrat'eva, 2020, p. 5). In the context of the COVID-19 pandemic, instruments for regulating foreign trade in goods have become a means of ensuring the food and medical security of the EAEU member states. Initially, on March 16, 2020, the EEC Council adopted its Decision No. 21, providing for the exemption from import customs duties of goods imported to prevent and prevent the spread of the coronavirus infection on the territory of the EAEU (EEC, 2020a). The decision applies to personal protective equipment, disinfectants, diagnostic reagents, certain types of medical equipment and materials.

On 24 and 31 March 2020, the EEC Board adopted decisions № 41 (EEC, 2020c), 42 (EEC, 2020d), 43 (EEC, 2020e), aimed at temporarily banning the export of personal protective equipment, protective and disinfectants, medical products and materials from the EAEU countries. On 25 March 2020, the EEC Council also adopted Order No. 11 on joint and coordinated actions of the EAEU member states on a wide range of issues in the implementation of such measures (EEC, 2020b). In particular, the member states agreed to exchange information and conduct 
operational consultations on the actions taken and national regulatory legal acts adopted in order to respond to the spread of coronavirus infection, coordinate the activities of national authorized bodies in the field of health care on an ongoing basis and ensure the sanitary and epidemiological well-being of the population.

On 10 April 2020, the members of the Eurasian Intergovernmental Council approved a set of measures to be adopted to ensure the vital needs of the population, support mutual trade and free movement of goods in the conditions of the COVID-19 pandemic and create conditions for subsequent economic growth (Eurasian Intergovernmental Council, 2020). There are two types of measures.

First, a package of urgent anti-crisis and stabilization measures, including:

- organisation of interaction of the relevant authorized bodies when carrying out sanitary and epidemiological measures to prevent and minimize the consequences of the spread of coronavirus infection

- creating a green corridor for the supply of critical goods,

- introduction of uniform time restrictions on the export of critical goods to third countries

- operational preliminary consultations at the level of members of the EEC Council on draft national legal acts aimed at introducing time restrictions related to the exceptional need to respond to the spread of coronavirus infection

- consultations of authorized bodies in the field of technical regulation

- temporary reduction or zeroing of import customs duties on components and materials for specific industries, taking into account their economic and social significance, etc.

Secondly, measures aimed at creating conditions for recovery and ensuring further economic development, including:

- ensuring macroeconomic stability and the sustainable functioning of financial markets and payment systems

- support for real sector enterprises

- the further digital transformation of trade, including wider use of electronic bills of lading and accompanying documents, digitized interaction of logistics operators, wider use of electronic digital signatures and technologies for automatic registration and release of imported, exported, and transit goods

- implementation of joint measures to create antiviral drugs and vaccines, as well as to establish their mass production

- maintaining and expanding access to public procurement for the functioning of the common market of the Union (ICLRC Report, 2021, p. 52-53). 
Some of the taken measures were of restrictive nature and were aimed at preventing the outflow of disease prevention and food products from the territory of the EAEU member States. Another set of measures was aimed at providing foreign trade participants with a number of benefits and simplifications in order to stimulate the influx of high-demand goods in the context of a pandemic, as well as medical equipment, medical products and medicines. During the aggravation of the situation with the coronavirus, a temporary ban on the export of personal protective equipment, protective and disinfectants, medical products and materials, as well as certain types of food products was introduced at the level of the EAEU.

As for the second set of measures to simplify trade procedures, two sets of tariff benefits were introduced at the level of the EAEU in the form of full exemption from payment of import customs duties (for goods of critical import and goods imported to prevent and prevent the spread of coronavirus infection). It is worth noting that in this area, the EAEU governing bodies acted more decisively than the European Union: the proposals of the European Commission on the introduction of a full or partial exemption from import customs duties and VAT for certain goods needed in the context of a pandemic were of recommendatory nature (IRIP VAVT Report, 2020, p. 11).

In general, perceiving the pandemic as a test for the EAEU, the Heads of the member states confirmed their readiness to continue cohesive work to eliminate the negative consequences of the COVID-19 pandemic, maintain the achieved level of integration cooperation, and the further economic development of the member states of the Eurasian Economic Union (EAEU Heads of State, 2020, April 14). And, indeed, despite the difficult situation, all the bodies of the EAEU during this period not only worked to overcome the crisis caused by the COVID-19 virus but also continued their routine, daily activities to promote the integration agenda of the organisation. For example, on May 19, the draft strategic directions for the economic development of Eurasian integration until 2025 were generally approved at the EAEU summit and eventually adopted in January 2021 (EAEU summit, 2020). The planned development strategy should lay the foundation for the activation of import substitution processes in the EAEU countries, the development of industrial localization and the promotion of joint initiatives with a high integration component. Thus, integration during the pandemic did not slow down for a moment. On the contrary, the entire Union, as well as each individual state, were mobilized and focused on effective joint work (Slutsky, Khudorenko, 2020, p. 125).

\section{OVERVIEW OF MEASURES TAKEN IN THE EAEU MEMBER STATES}

Along with the measures described above, the EAEU member states separately addressed the following non-tariff barriers to exports: 
- a ban on exports. It is important to note that some countries prohibited the export not only within the framework of the customs export procedure, but also other customs procedures: for example, in Belarus, there was a temporary ban on the export, re-export, processing outside the customs territory, temporary export of personal protective equipment, protective and disinfectants, medical products and medical equipment;

- quantitative export restrictions (introduced by Kazakhstan and Russia). For example, Russia imposed temporary quantitative restrictions on the export of grain crops;

- permissive export procedure (introduced by Armenia in relation to medical products). It involves obtaining a license or permission to export goods that are subject to restrictions.

It should be noted that the measures of the majority of the EAEU member states restricting exports were introduced against all third countries, including, unfortunately, the states of the Union. Only Russia has excluded the EAEU members from the temporary restrictions on the export of grain crops outside the country.

At the same time, the analysis of trade statistics shows that Belarus and Kazakhstan accounted for a significant share of the deliveries of goods to the Russian market necessary to combat the pandemic ${ }^{2}$ for which export bans were imposed (EEC, 2021). For example, 10.4\% of other medical headwear on the Russian market, according to the results of 2019, came from the Republic of Belarus, and the Republic of Kazakhstan accounted for $6.7 \%$ of all deliveries of protective medical clothing.

With regard to imports, the EAEU member states imposed bans and restrictions with reference to the sanitary and phytosanitary measures. In particular, Russia had a temporary restriction on the import and transit through the country of all types of exotic and ornamental animals from China (on 19 May, the restriction was lifted).

It is important to note that during the "peak" of the coronavirus pandemic, there was a discrepancy in the actions of the EAEU member states regarding the transit of goods within the Union, which led to the formation of additional barriers.

Thus, Armenia demanded compliance with the self-isolation regime by international drivers. Belarus has limited transit time: road transport transiting through Belarus has to leave its territory no later than the next day.

\footnotetext{
${ }^{2}$ The World Health Organization has identified 17 products that are considered key in the fight against the COVID-19 pandemic. These include: diagnostic and therapeutic supplies, including enzymes, hygiene products (liquid soap and hand sanitizers), personal protective equipment, including gloves and medical masks, and personal protective equipment such as oxygen concentrators and respirators.
} 
The EAEU member states have also introduced measures to simplify trade procedures at the national level. A common practice has become the launch of "green corridors", which allow national participants of foreign economic activity to avoid some customs formalities and promptly carry out customs clearance of the imported consignment.

For example, in Kazakhstan, the "green corridor" granted importers of socially significant goods an exemption from inspection, examination, control of customs value. In Russia, the "green corridor" was opened for essential goods and food: according to the order of the Federal Customs Service of Russia, the customs authorities had to ensure a priority procedure for performing customs operations in respect of such goods, speeding up their release into free circulation.

In some EAEU member states, the fiscal burden on foreign trade participants has been reduced. For example, in order to stabilize the food market and the agricultural and industrial complex in the conditions of the pandemic, Kazakhstan resorted to tax incentives. Thus, the VAT rates on the import of socially significant food products were reduced, and the import of biological assets of the agroindustrial complex (cattle and breeding chickens) was exempt from VAT.

In Russia, in addition to the tariff benefit (exemption from payment of import customs duties), which was introduced at the level of the EAEU in respect of goods imported for the prevention and control of coronavirus infection, the Government of the Russian Federation approved a list of medical goods that were also exempt from paying import VAT.

\section{CONCLUSION}

The legal regulation of various issues, including healthcare and overcoming the pandemic, within the framework of international regional integration organisations differs depending on the level of integration of the member states of the relevant entity. There are no such mechanisms in the EAEU since this integration organisation is focused more on the freedom of trade between the member states and the implementation of a coordinated policy in economic sectors than on health issues. So, at the level of the EAEU, measures were taken, on the one hand, to abolish duties on the import of goods intended to prevent the spread of COVID-19 on the territory of the EAEU, and on the other, to introduce a temporary ban on the export of such goods from the EAEU countries.

At the same time, measures to help stabilize the economic situation at the level of the EAEU were taken. Nevertheless, it seems that the establishment of more detailed regulation at the supranational level regarding the adoption by states of agreed measures in the areas of trade and economy during emergencies, and then 
their national implementation, can contribute to a more effective response to challenges such as the COVID-19 pandemic in the future. At the same time, the effectiveness of the implementation of these measures is not obvious. There is no information about the intensity of communications between the EAEU countries in the context of a pandemic.

It should also be noted that during the aggravation of the situation with coronavirus, the restrictions were imposed on the export of personal protective equipment and food at the level of individual EAEU member states, which were applied to all third countries, including other EAEU member states. It seems that the issue of introducing such measures in emergency situations should be coordinated promptly with other members of the EAEU, so as not to cause an aggravation of the shortage of necessary goods in the Union space but, on the contrary, to ensure the optimal distribution of such goods. In case of the impossibility of preliminary approval, the interested members of the EAEU should be given the opportunity to promptly hold consultations with the state of the Union that introduced the restrictive measure.

The inconsistency of the actions of the EAEU member states regarding the transit of goods during the pandemic led to the formation of additional barriers that prevent the free movement of goods. The resolution of such a situation is possible in the case of expanding the competence of the EEC as the main regulatory body of the Union. The institutional structure of the EAEU is determined by the principle of the institutional balance of national and supranational interests, which is inherent in the Union. Moreover, such a balance should not be unchanged and should include the evolution of the legal status of its bodies. This should correspond to the vector of development of regional integration, the goals set for the Union by the participating states, as well as the principles that are laid down in the basis of its functioning, especially in the context of the ongoing COVID-19 pandemic. Nevertheless, certain innovations are necessary besides the above-mentioned expansion of the powers of the EEC. The introduction of elements of accountability of the state authorities of the member states to the Commission, the introduction of elements of responsibility of the participating states for non-fulfilment of their obligations arising from membership in the Union should help in the successful development of the Eurasian integration project and ensure its resilience.

\section{REFERENCES}

Bagenstos, S.R. (2020). May Hospitals Withhold Ventilators from COVID-19 Patients with Pre-Existing Disabilities? Notes on the Law and Ethics of Disability-Based Medical Rationing, Yale Law Journal Forum, 130, retrieved from 
https://www.yalelawjournal.org/forum/who-gets-the-ventilator. Accessed 1 June 2021.

Betskov, A.N., Tagirov, Z.I. (2017). Sistemyupravlenija v chrezvychajnojobstanovke: mezhdunarodnyjopytivozmozhnosti ego ispol'zovanija v Rossiii v gosudarstvahchlenahEvrazijskogojekonomicheskogosojuza, Problemybezopasnostiichrezvych ajnyhsituacij,6, pp. 3-13 [Betskov, A.N., Tagirov, Z.I. (2017). Emergency Management Systems: International Experience and Possibilities of Its Use in Russia and in the Member States of the Eurasian Economic Union, Problems of Security and Emergencies, 6, pp. 3-13].

EAEU (2014). Treaty on the Eurasian Economic Union, retrieved from https:// www.un.org/en/ga/sixth/70/docs/treaty_on_eeu.pdf. Accessed 1 June 2021.

EAEU summit (2020). ReshenieVysshegoEvrazijskogojekonomicheskogosoveta № 12 ot 11 dekabrja 2020 goda «O Strategicheskihnapravlenijahrazvitija evrazijskojjekonomicheskojintegracii do 2025 goda», retrieved from https:// docs.eaeunion.org/docs/ru-ru/01228321/err_12012021_12. Accessed 1 June 2021.

EAEU Heads of State Instructed Governments and Central Banks to Coordinate Measures to Combat COVID-19 (2020, April 14), retrieved from https:// www.economy.gov.ru/material/news/ekonomika_bez_virusa/glavy_gosudarstv _eaes_poruchili_pravitelstvam_i_centrobankam_koordinirovat_mery_po_borb e_s_covid_19.html. Accessed 1 June 2021.

EEC (2020a). ReshenieSovetaEJeK № 21 «O vneseniiizmenenij v nekotory ereshenijaKomissiiTamozhennogosojuzaiobutverzhdeniiperechnjatovarov, vvozimyhnatamozhennujuterritorijuEvrazijskogojekonomicheskogosojuza $v$ celjahrealizaciigosudarstvami - chlenamiEvrazijskogojekonomicheskogo sojuzamer, napravlennyhnapreduprezhdenieipredotvrashhenierasprostranenija koronavirusnojinfekcii 2019-nCoV», retrieved from: https://docs.eaeunion.org/ docs/ru-ru/01025251/err_24032020_21. Accessed 1 June 2021.

EEC (2020b). RasporjazhenieSovetaEJeKot 25 marta 2020 goda № 11 «O realizaciimer, napravlennyhnapredotvrashhenierasprostranenijakoronavirusnoj infekcii COVID-19», retrieved from https://docs.eaeunion.org/docs/ruru/01427 832/err_30032020. Accessed 1 June 2021.

EEC (2020c). ReshenieKollegiiEJeK № 41 «O vneseniiizmenenij v Reshenie KollegiiEvrazijskojjekonomicheskojkomissiiot 21 aprelja 2015 goda № 30 «O merahnetarifnogoregulirovanija»», retreived from https://base.garant.ru/ 73806228/. Accessed 1 June 2021.

EEC (2020d). ReshenieKollegiiEJeK № 42 “O vneseniiizmenenij v perechen' tovarov, kotoryejavljajutsjasushhestvennovazhnymidljavnutrennegorynkaEvrazijskogojek 
onomicheskogosojuzai v otnosheniikotoryh v iskljuchitel'nyhsluchajahmogut byt' vvedenyvremennyezapretyilikolichestvennyeogranichenijajeksporta», retrieved from http://www.consultant.ru/document/cons_doc_LAW_349222/ 92d3e3d03094ed76da5c15fa72b687f1cebd593. Accessed 1 June 2021.

EEC (2020e). ReshenieKollegiiEJeK № 43 «O vneseniiizmenenij v ReshenieKollegii Evrazijskojjekonomicheskojkomissiiot 21 aprelja 2015 goda № 30 «O merahnetarifnogoregulirovanija»», retrieved from https://docs.eaeunion.org/ docs/ru-ru/01425280/err_02042020_43. Accessed 1 June 2021.

EEC (2021). Statistics of foreign and mutual trade in goods, retrieved from http://www.eurasiancommission.org/ru/act/integr_i_makroec/dep_stat/trades tat/Pages/default.aspx. Accessed 1 June 2021.

Eurasian Intergovernmental Council (2020). PostanovlenieEvrazijskogomezhpravitel' stvennogosovetaot 10 aprelja 2020 goda № 6 «O merah, prinimaemyh v ramkahEvrazijskogojekonomicheskogosojuza po obespechenijujekonomicheskojstabil'nosti v uslovijahrazvitijapandemiikoronavirusnojinfekcii COVID-19, retrieved from https://docs.eaeunion.org/docs/ruru/01425377/ico_16042020 _6. Accessed 1 June 2021.

Ferhani, A., Rushton, S. (2020). The International Health Regulations, COVID-19, and bordering practices: Who gets in, what gets out, and who gets rescued?, Contemporary Security Policy, 41:3, pp. 458-477. DOI: 10.1080/13523260. 2020.1771955.

Government (2007). Decree of the Government of the Russian Federation of 21 May 2007 No. 304 "On the classification of natural and man - made emergencies", retrieved from https://rg.ru/2007/05/26/chs-dok.html. Accessed 1 June 2021.

Gromyko, A.A. (2020). Koronaviruskakfaktormirovoipolitiki, Scientific and Analytical Bulletin of the Institute of Europe RAS, 2(140), pp. 5-13. [Gromyko, A.A.(2020) Coronavirus as a Factor in World Politics, Scientific and Analytical Bulletin of the Institute of Europe RAS, 2(140), pp. 5-13].

Guterres, A. (2020). This is, above all, a human crisis that calls for solidarity, retrieved from https://www.un.org/en/un-coronavirus-communications-team/above-allhuman-crisis-calls-solidarity. Accessed 1 June 2021.

Holm, S. (2020). A general approach to compensation for losses incurred due to public health interventions in the infectious disease context, Monash Bioethics Review,38(Suppl 1), pp. 32-46. DOI: https://doi.org/10.1007/s40592-02000104-2.

ICLRC Report (2021). Covid-19- Test for the World's Legal Systems, retrieved from https://iclrc.ru/en/research. Accessed 1 June 2021. 
IRIP VAVT Report (2020). Posledstvija pandemic dljarazvitijastran EAJeS: opytantikrizisnyhmer, urokidljaperspektivintegraciiDoklad IRIP VAVT, s uchastiem InstitutaissledovanijijekspertizyVJeB.RFSentjabr' 2020 [Impact of the pandemic for the development of the EAEU countries: experience of anti-crisis measures, lessons for integration prospects September 2020], retrieved from https://vavtirip.ru/digest/analitika/posledstviya-pandemii-dlya-razvitiya-stran-eaes-opytantikrizisnykh-mer-uroki-dlya-perspektiv-integr/. Accessed 1 June 2021.

Kondrat'eva, N.B. (2020). Rabotainstitutov EAJeS v uslovijahkoronakrizisa, Analiticheskajazapiska №26, №209. [Kondrat'eva, N.B. (2020). The work of the EAEU institutions in the context of the coronavirus crisis, Analytical note No. 26, No. 209] DOI: http://doi.org/10.15211/analytics262020.

Slutsky, L.E., Khudorenko, E.A. (2020). EAES: urokipandemii, Comparative Politics Russia, 4, pp. 123-134 [Slutsky, L.E., Khudorenko, E.A. (2020). EAEU: Pandemic Takeaways, Comparative Politics Russia, 4, pp. 123-134] DOI: 10.24411/22213279-2020-10053.

WHO (1946). Constitution of the World Health Organization, retrieved from https://www.who.int/governance/eb/who_constitution_en.pdf. Accessed 1 June 2021.

WHO (2005). International Health Regulations, retrieved from https://www.who.int/ health-topics/international-health-regulations\#tab=tab_1. Accessed 1 June 2021.

WHO Director-General (2020).Opening remarks at the media briefing on COVID19-11, March 2020, retrieved from https://www.who.int/dg/speeches/detail/ who-director-general-s-opening-remarks-at-the-mediabriefing-on-covid-19-11-march-2020. Accessed 1 June 2021. 